ては心史じに編はて堂内蓮

い堂にをめよ集しかい域に信身

る宇、紐とり、かつる。抑延

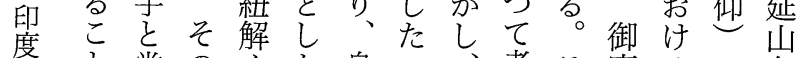
と堂の々た身可考こ廟るの岁 は宇中鍵延身近察の所信根遠 評をにと従山延年し各域仰幹寺 価結あな来内山、た地、或市的 さぶるっ明の久身。域奥地位

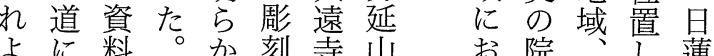
う注が研で公内院域つて廟

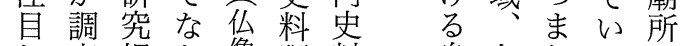

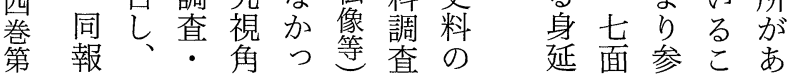
号告動活とた。蕔発山詣とる 号書線用し資絵告掘信域場は霊 平のにさて料画書や仰、所周場

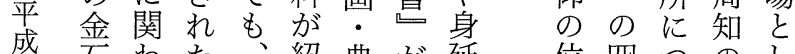
は
ほ
に 石わた、紹典が延位四つのし 七文るが従介籍刊町置籄いこて 年の資、来さ行教哲てと祖

土項料こはれ金さ育林はで師

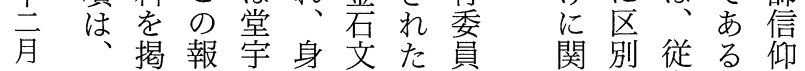
身載告を延をこ会しさ来。

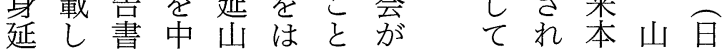

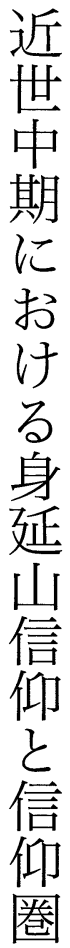

に加信資討ををる門廟れ院山 至し近仰料し中本資域所て域内

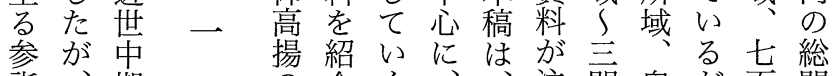
詣、期 近 の介く。方門奥が面門

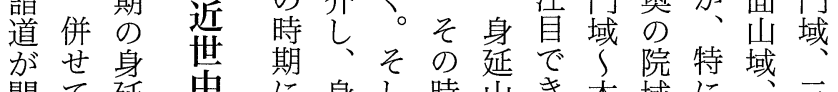

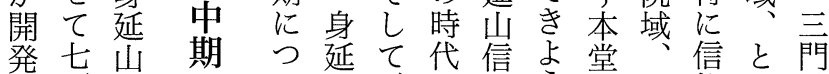
さ面はの い山地う域七仰い域 れ山身てに身信の。面関っ た信祖延㐫妳仰信本山係た御 仰師山てけ山者仰堂域資七廟 七の信といる信の圏域の料箇所 面高仰と参こ参仰居を 山揚の 参 こ 詣詣の住探奥に確て 分本 のと揚場に所れ及手院認はけ堂

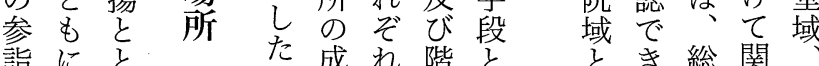

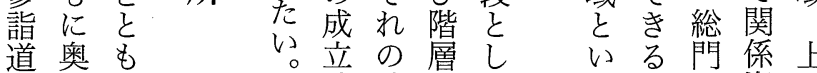
はのに時地にてっ資の 院参期域着、たそ三料山 後や詣雀に貝近道し㑚が域 述七者身伝し、世程て、域紹 自が延わ虫河、奥 る山増山山る検期 あ総御さ の 
の建に東は各の時身こい山延山山よ

武武階袁よ立六谷坊師期延のる絵山とやう

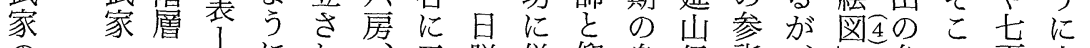

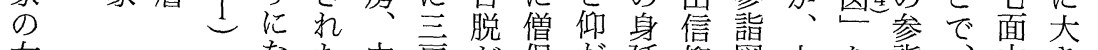

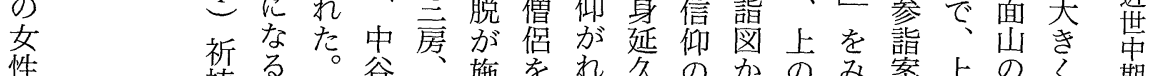

性䘠る。谷施をれ久の加のみ案上のく期

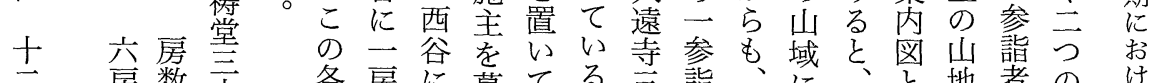

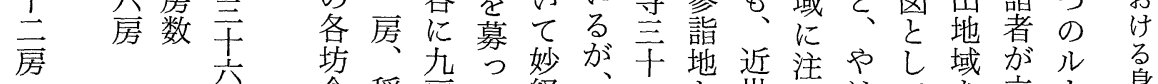

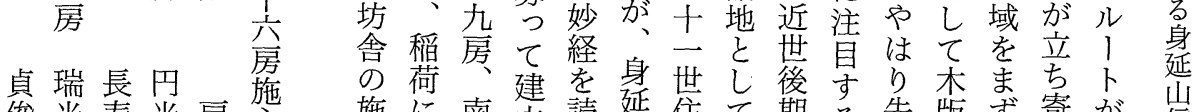

俊光寿光房主施に南立読延住て期る先版ず寄が信

房房房房名の主二谷し誦山持位のと述刷概る あ 仰

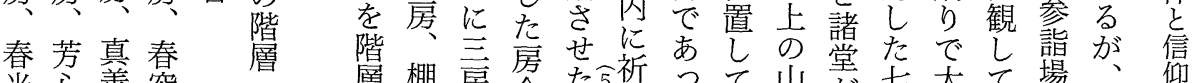

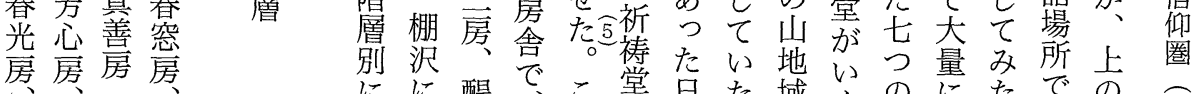

$\begin{array}{ll}\text { 侮慶 } & \text { 清 } \\ \text { 雲 } \\ \text { 房房 }\end{array}$

芳妙松

春店房立房

にに醍でこ堂日た域くのにたでの

み二醐上の主脱わはう信印いあ山山望

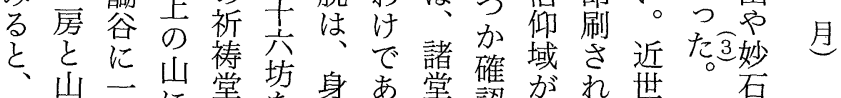

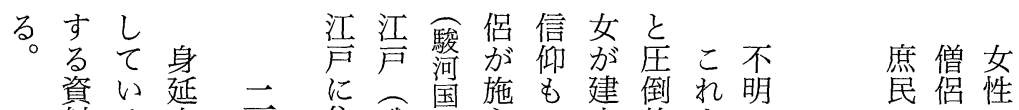

料る本一住武国主み立的を

や。院上蔵儿立らしにみ

紀こ吕全国公なれた多る

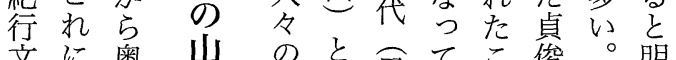

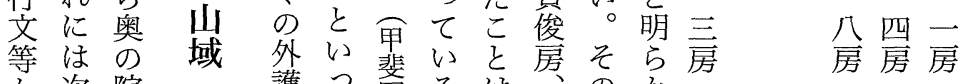

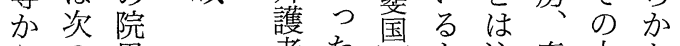

らの思者た覜も注春中な

み 二 親

がこ富の目光によ長信浄宗法見仙高

てつ閣

いのに

くル 至

と、! る

次 が筋

の 存に

参 在 堂

詣守宇

路るや

が。資

確 堂 料

認宇 が

でに点

き関 在

確と畐でで房はう安了蓮幸䕐塔台雲

認から声 あきが江に房房房房房房房房

き身鵔が、り、城武清 定渋顕

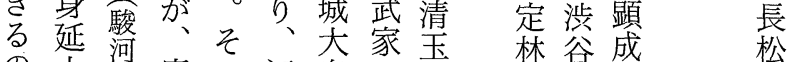

で近国庶の江奥の房房房房他房

あ隣精のは城中性妙実常本 清

る。精住武南梅の善道栄学輝

斐川售居家奥の施房向房房房方房

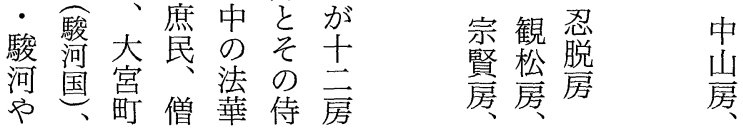


近凘

世 (3)

本身水了水本

に堂延与法稚堂延水歲本身

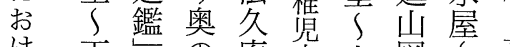

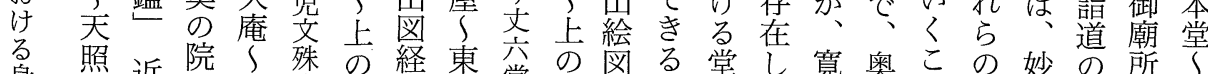
身照近院 富殊の経東堂の図る堂し寛奥この妙の所堂

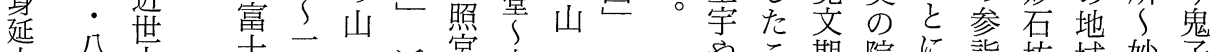

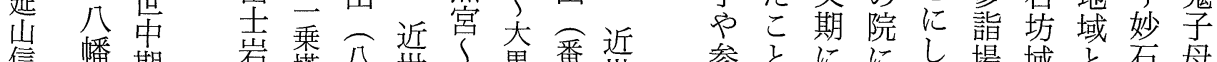
信幡期岩塔八世幡世黑番世近参とににし場域と石母

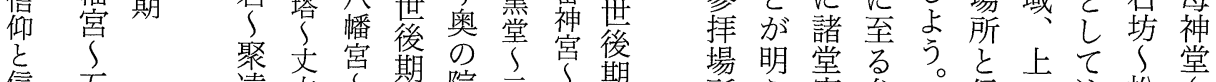

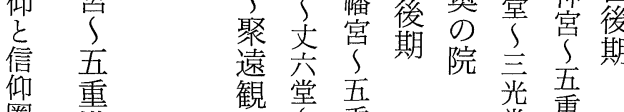

圈 塔

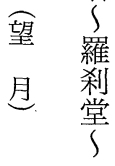

切

経
東龺塔

照趋 鬼

龍 恶 㭧

$\square$ 堂神

踷鉄交
堂重

与稚

鉄 児

仏交

常

題 乗

貝堂
資資の地或有着。来こ

料料参地が堂眼そしのルル

(1) 加詣域存少しこて中! 所 5 宇参。信の注松了 のかが詣徒山目樹丈 存々移道層域さ黁六 在な転の港年堂 はっさ中つ奥、願 て怙にいの信渾三 主い卡院仰稻光 にる身の 、山関荷堂

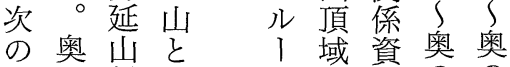
至の信い卡衉料のの 亏院仰う (1) 市院院

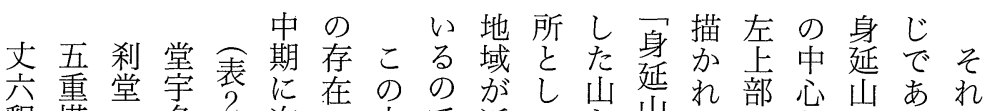
釈塔堂名已次は中で近て山禁部心山热

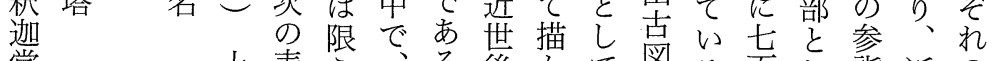

堂 上表方手後古て図 る面し詣近の石現 寛寛寛移の 2 れ上。期れはでこ山て案世記了宮稚

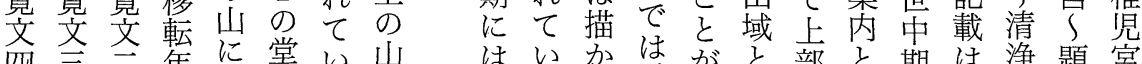

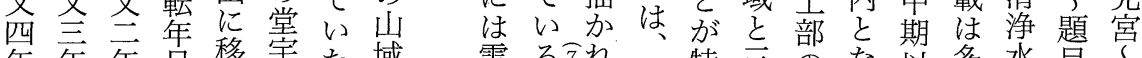

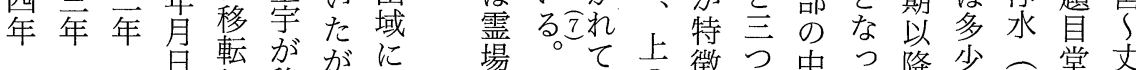

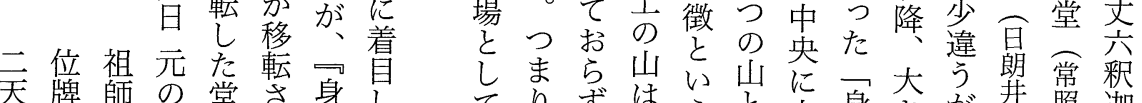

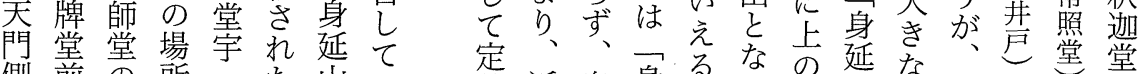
側. 前の所二た山み定近奥身るなっの延な上堂堂

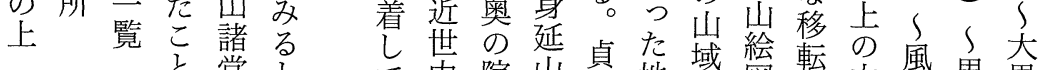

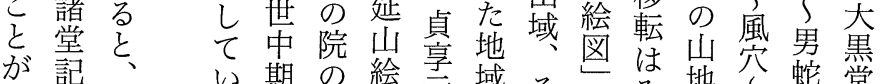

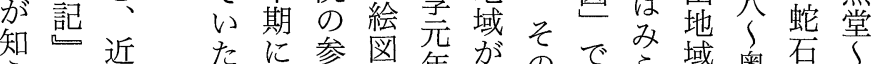
らに世近怎成参図年参のでら域奥石了

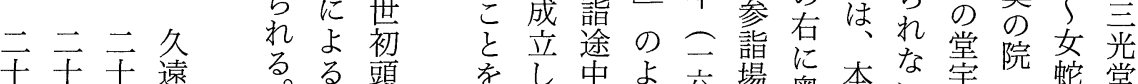
八八分公に物たのう八所の奥堂はは石了 世世世住近堂語上参に四々院域特ほ独葽照

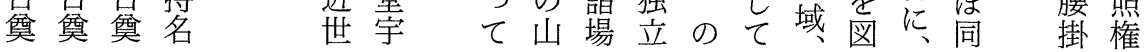




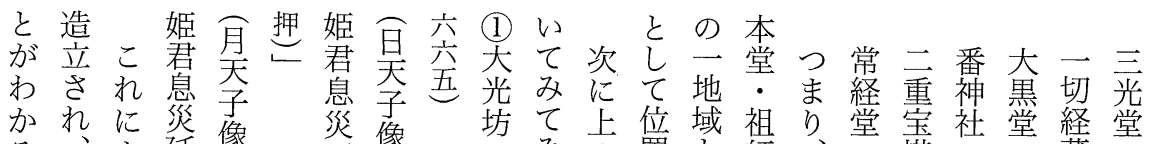

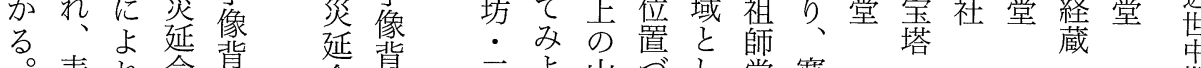

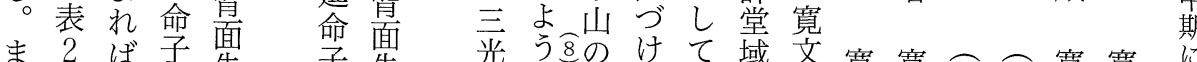

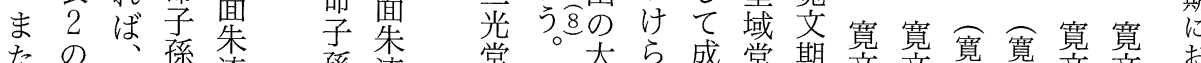

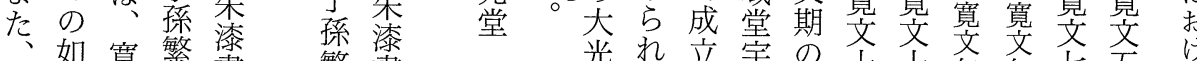

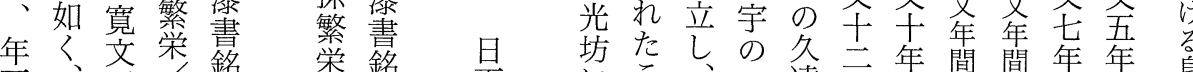
不五宽銘栄銘吴にこ、溒年年間間年年身 詳同年寛一 で年へ文南 あに二五無 る言六年型 が恶六角 堂五兵无 身堂に五 延宇是旦 山粕呑亩揵 奥建子旦府 の立・凨莘 院さ月 相 宝犯花綱 塔た子押重 施こがし局

寛南手

寛無南けが詣が二

文無兵

五旦堂名記山世

年天立・可域昌

十王像仏で参に擮

十 銘 像学㩐移

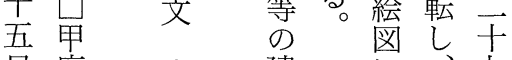

日府寛建江九

宰文立

奠綱年期

花重 二
参身世趾市市市市市 詣山赳世世世世世世 場信代百百百昌

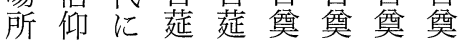

(3) (2) 1) ピ の地の信野

嶋道/講祖釘祖 ツ妙つ・信徒本近 河標願中師屋師ク石な階仰と洋世 成銘主/堂八像ア坊が層がの氏に 嶋九・郎台ツ。内りに明関のお 村宝江日祈兵座プにかつら係論け 歴户講願衛銘し市らいかい考る 望五浅中札講路て あ 考て、につが妙 月年草/銘中宗み信毜、ないあ石

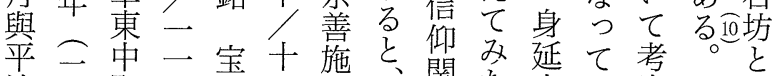
治七町日永二主次関た山い察そ信

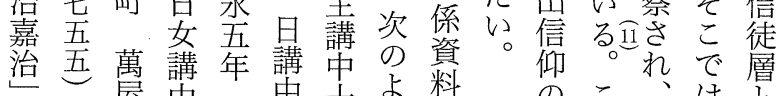

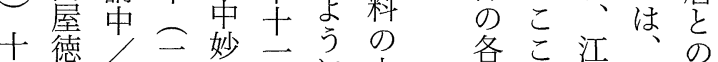
二兵二七因人に中場でき近関 月衛三○兵所は市世係 日

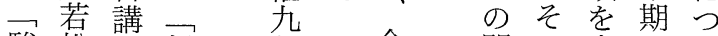
駿松中祖郎金関の中心い 河屋/師十石係信心妙て 国茂一講云文仰と石は 富兵九中 葦 郡講八出道居庶持に 賀 中日

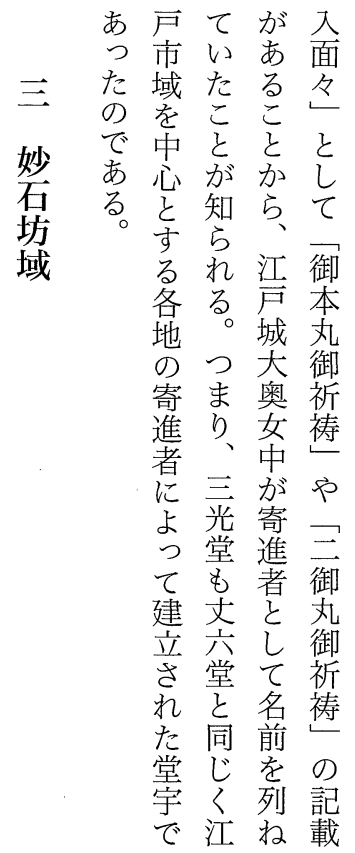


中 認

(11) (10) (8)

(7)

(6)

(5)

しでこ名 / 妻三旦斐祖像妙口法山妙柳妙糟江尾清 近てきれ樑

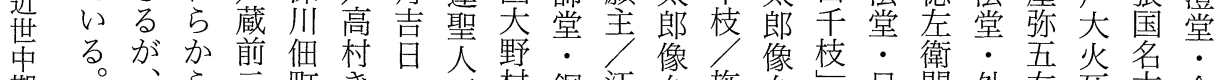

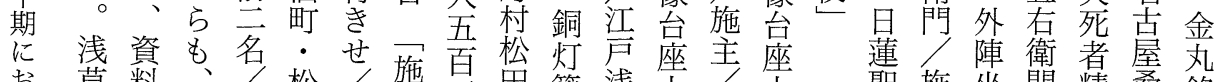

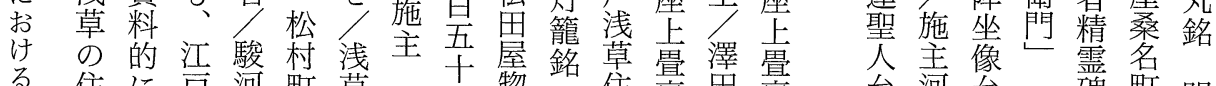

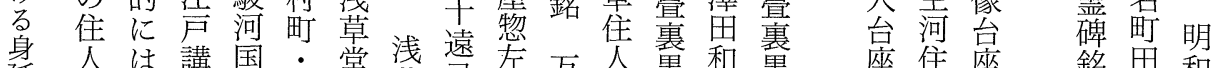

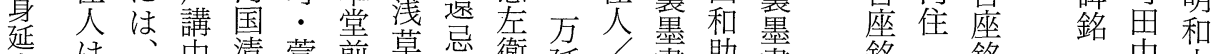

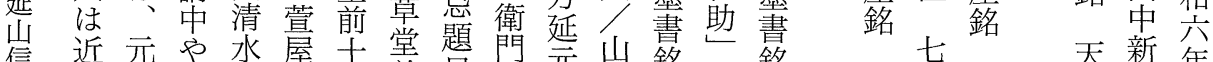

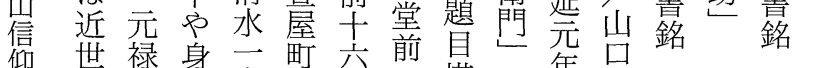

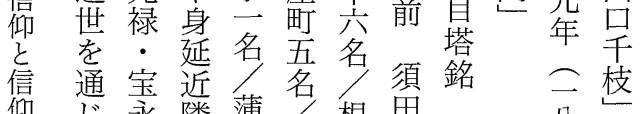

仰荿永粼蒲名根田

圈て期地原神津 文

望妙そ域名思䦗夕政

坊し人岁前須立

諸幕の淵浅名思年

諸幕存名草牛せ气

掌期在名堂込少公神

寄集確篎名坂元

願

記こ身彼無浄 か鷲高養脱怒宝祖享䓪祖資次

(4)

突星旦

年 壱嘉

月竞洜

天新年

さに延月始土る山祖塔判・年堂六十堂を、

机は奥氏之に不尔大

て大觉罪扔思志菩天

い坂院䚖障と議て薩明

る河鹋をる乃相御三

が内旦出消遍法傳書年

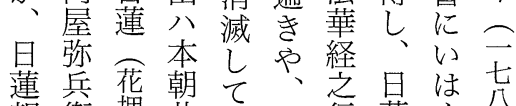

報衛押此主此行蓮々

恩家䠶業难者が、芳教五

貝怠悪り售團主韋

形妙○赏年三袁紹奥

蓮六六气年日介の

像六老二蓮し院

像分老志蓋像て域

再售三六文像

興更九像已亲占抒

月百京至。け

保六

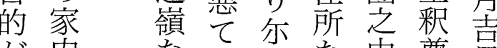

が内尔んのな中尊

主安利じぞれ尔之

で全南てまば加六

あ方南恶ん㚐

り、尒無德々少持事

こ繁滛ながでて悡

れ栄蓮ながから法

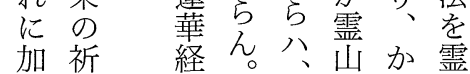

天午昭都五

和言伀青信

二百日師土仰

年朗 伊主関

二各・藤日栠

奥 て

院

院る

域 の

で

る。

亲堼昷腃衣交料

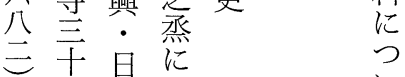

四世向占尔

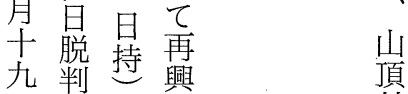

日 形金延近 


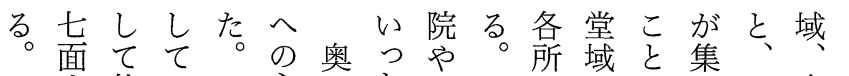
山位い二主のた七こに感が本书 信置く方要院こ面の諸ら注ら干堂山 仰づに、去と山上堂の目机八域内 のほ伴妙!詣吕参の掌さ、世纪 重らい石卜道考挷山が宇机身百奥扔

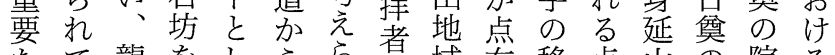
な龍老し占者域在移点山院る

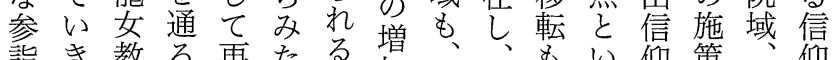

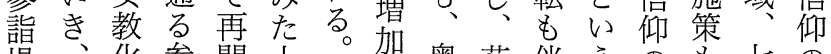
場、花参開上。加奥荘伴光の西七の

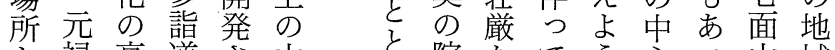
と禄高道さ山热院なて

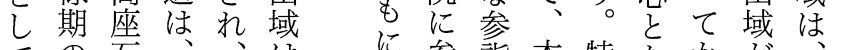
て石注 形七具登宦 成面七蓮展䔈 さ信面とし文 氺山龍て

ての需女い延 い高場のく宝 揚 伝こ䔮 たとの説とに の 基がに奥 でも点定なの あ结着っ院
庶参詣本特なか力

磨詣場堂治る、西総

民票所域、上る門

のると莧地のが域

信途な背文域山、

仰中方後期飞域近三

対でてに尔を門

象あい篮上っ中中域

とりた学のて心期

な、のる山いに御

つ奥で山はつ諸な廟

てのあの本た堂る所

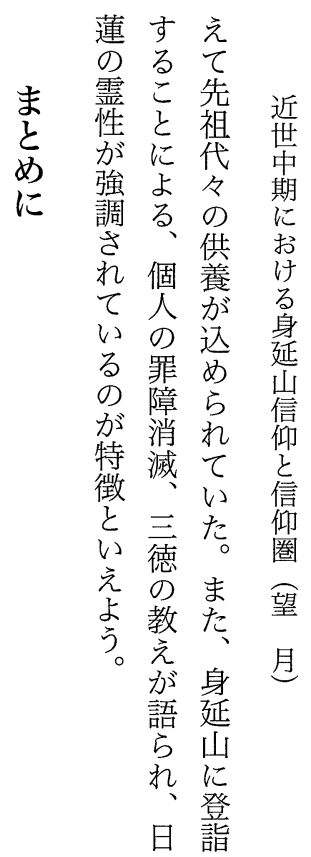

延図諸 ${ }^{3} \boldsymbol{Z}^{1}$

山経堂近拙い拙

図記世著る著

経等器の前。

研あ身莚畫世 近

究る。延山

藤後坊堂

滕者跡宇

井百録や

晃点、参

光編刊身詰

著行編延道

島年山関

身に絵守

鑑い圂る

鑑いて基

解は身本文

題、延齐

を参洮鑑は

照光的身

れ口延延

た身山山
た域

のし仰がて種料みの大地

いの今寄たの多はのにせ人奥域妙 相後進の証く人登て々女石 互の行でし、浅々場いも中し坊 関課為あと近草かしたみのての 係題をるし世学、はてこら存は金 がと積。て中日知くと在石 あし 極まの期本るるが、も全文 げて的た題か橋こ人い主確体や ら、に貝方物えに認的信 れ身行扁塔幕深がのる都さに仰 る延つ額を末娄川で階の市れ江関 が山てや建期とき層で部た戸係 内い仏立まいなはあを市市資 このた具しでつい名域料 れ信こ銘、盛た。庶。心古がか に仰とか身え地し民金に屋多ら つ地がら延に域か が石身やく、分 い域知し山身のし主文延大、析 てのらての延肩、省崖坂庶し は成れ、年山書江あは信と民た 稿立る。堂中にを声るじ仰い層結 を時宇行登持市がめがつか果

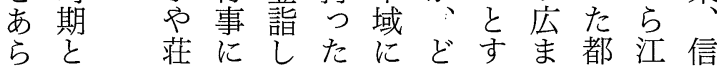

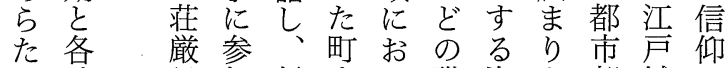
め地具加信人い職資を部城の 


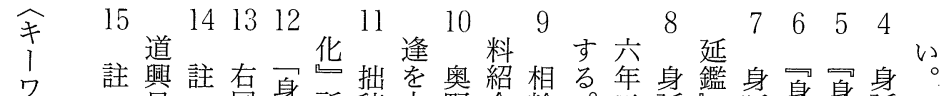

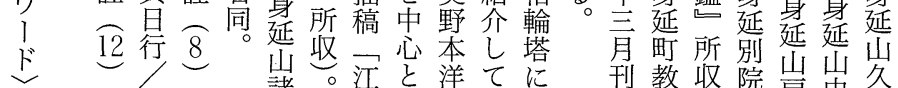

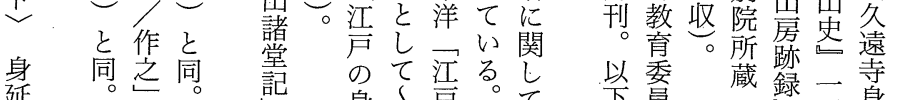
䏍。所房更遠 以委蔵録一寺

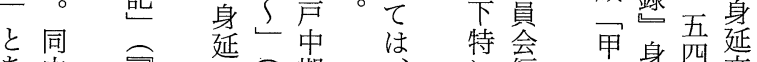

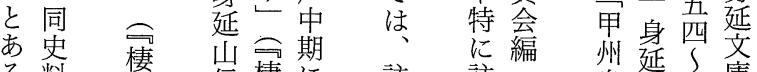

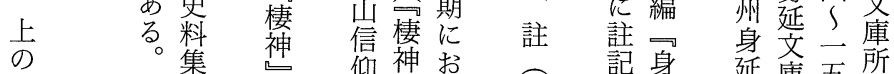

山्

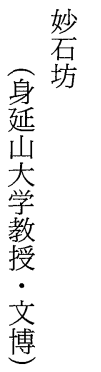

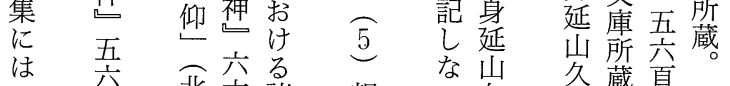

$\begin{array}{cc}\text { 信 } & \\ \text { 望 } & \text { 身 } \\ \text { 望 } & \text { 延 } \\ & \text { 岁 } \\ & \text { 教 } \\ & \text { 授 } \\ & \text { 文 } \\ & \text { 博 }\end{array}$
$\begin{array}{ll}\text { 佂 } & \text { 号 } \\ \text { 寶 } & \text { 載 } \\ \text { 八 }\end{array}$ 北六諸報次藏頁 原号堂告史遠堼 進所宇畫料寺絵

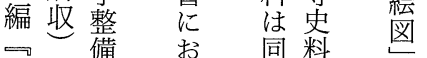
近が備抒同料㡙 世主つ藤 のない坂集報井 地も 思揭告 日 域の学正載畫光 配あ椫氏平著

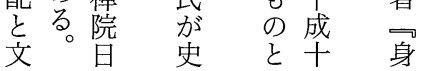

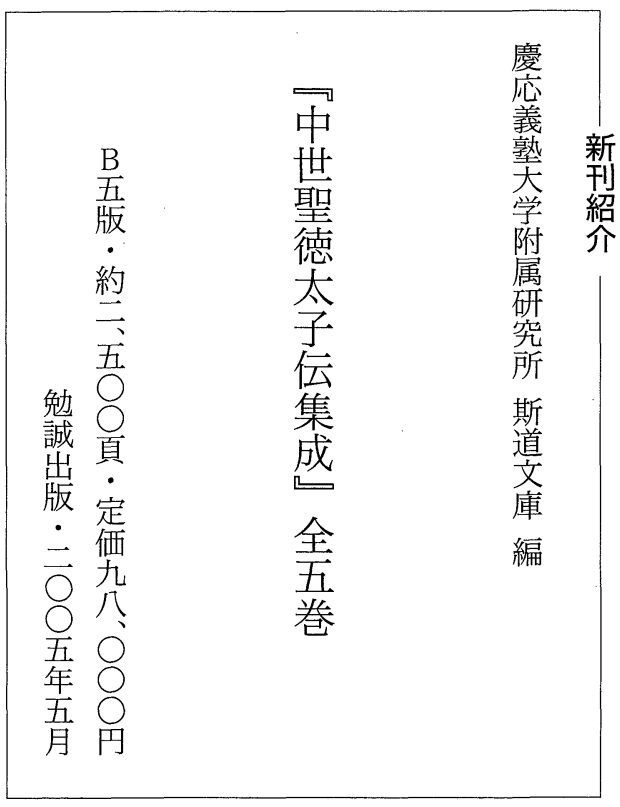




\section{The Hell Picture of Nozoki Karakuri}

Kiyoshi NEI

Nozoki Karakuri is a street performance. It took place in the 17th century. Spectators watch moving dolls and pictures, and so on, through a glass window in a box. Among the painted pictures, many were drawn from the idea of Buddhist Hell and Paradise. Nozoki Karakuri has been preserved in Fukae town, Nagasaki prefecture. It is one of the cultural treasures of Japanese Buddhism.

\section{Religion of Minobusan and religion area in modern period}

Shinchō MocHIZUKI

Minobusan Kuonji-temple is Nichiren's hallowed ground. Nichiren lived in Minobusan in over nine years. Minobusan's hallowed ground was formed in medieval time.

This paper inquires into the time and places of worship in Minobusan region on the basis of their relevant materials.

\section{Fujaku's View of the Huayan Thought}

Ryō NISHIMURA

Fujaku (1707-1781) was a scholar-monk representative of the early modern period in Japan. He idealized the times of the historical Buddha and as a Vinaya monk practiced the Four-Part Vinaya. Scholarship to date has defined Fujaku as a heretic from the traditional doctrines. Huayan scholars have also criticized Fujaku's Huayan thinking, claiming that he is biased toward practice.

Fujaku considered the five kinds of teaching classified by the Huayan as something practiced by himself over a distance of many lives. The Huayan philosophy has supported his practice from the present time to the time of his becoming a Buddha in the distant future. Fujaku's approach integrates 